\title{
Designing a Safety Management Model for Higher Education Centres
}

\section{Yasamin Molavi Taleghani ${ }^{1 *}$, Alireza Jabbari ${ }^{1}$, Elahe Khorasani ${ }^{2}$, Hori Asgari ${ }^{1}$ and Raja Mardani ${ }^{1}$}

${ }^{1}$ Health Management and Economics Research Center, Isfahan University of Medical Sciences, Isfahan, Iran

${ }^{2}$ Department of Phamacoeconomics and Pharmaceutical Administration, School of Pharmacy, Students Scientific Research Center, Tehran University of Medical Sciences, Tehran, Iran

\begin{abstract}
Background: The pattern of safety management in higher education centres can prevent the complications caused by harmful issues to students and bring their potential talents closer to perfection. Therefore, this study was conducted with the aim of designing a safety management pattern in higher education centres of Iran in year of 2016.

Study design and methods: The present study was a descriptive study from qualitative type. This study was conducted in 3 independent phases including: (evaluating theoretical concepts for evaluating safety management models in educational and non-educational organizations of the world, developing an initial model by determining the points of sharing and differentiation of the evaluated models and validating the safety management pattern using the Delphi technique). Descriptive statistics (frequency, percentage, and mean) by SPSS-22 software were used to analyse quantitative data and the consensus of experts was used for analysing qualitative data.
\end{abstract}

Results: In the first stage, 111 indexes were identified by reviewing the studies and evaluating the safety models in the world's educational and non-educational organizations for the 12 main categories of safety management model. In the Delphi phase, with $82 \%$ reliability, 82 components were identified as a key index of the safety management framework in higher education centres of Iran. Also, the average mean of participants' views on the dimensions of the Safety Management Framework for Higher Education Centres has been 4.32, with the highest average mean related to the dimension of the facility and the firefighting department with a mean of 4.59 and the lowest for the student dimension with mean of 4.10 .

Conclusion: The indexes presented in this study will provide a fairly complete tool for designing safety management in higher education centres, which by applying it will provide a good opportunity to improve the performance of these systems over time. Therefore, it is essential to establish a safety management system in higher education centres with command lines and delegating authorities and organizational and legal tools.

Keywords: Safety management; Pattern; Higher education centres

\section{Introduction}

The structure of the school or university, the quality of education, the combination of educational and non-educational staff, along with the complex environment of the educational centres, creates conditions that are important for the search and evaluate the status of safety in order to improve and extend the situations and opportunities for the educational process [1]. Therefore, the educational safety and continuity in schools and universities require a continuous and dynamic process initiated by the management and the involved staff, students, parents and the local community [2].

Many educational centres every year suffer from disasters and a significant number of students and staff members of these centres are victims of disasters [3] in a report, which was conducted using the data collected from the Marsh's Higher Mental Health Risk Management study (2010), uncertainty in finances, competition among students, international registration, population and deficiencies in the perception of risk and safety management programs, was expressed As key issues of safety management programs at higher education centres [4]. Also in the usage guide of risk management at the University of London, withdrawal from the budget, the collapse of key markets which lead to significant loss of earnings, college dissatisfaction with customer service and college missions, inability to manage dormitories (power outages, firefighting, etc.) and damage to university reputation by negative media coverage was mentioned as the dangers of university and higher education centres [5]. Therefore, it is necessary to have a specific structure and pattern of safety management for preventing disasters and coping with risks, taking into account the health and safety of staff, customers and other stakeholders in higher education centres or schools.

Safety management is the process of identifying, analysing and forecasting risks that are considered a threat or risk for organization. Therefore, safety management is an organized attitude to risk management in an organization [6]. Following the systematic patterns and methods in safety management can guide the organization to reach the causes of disasters in a logical way and direct away them from pursuing an unstructured approach based on mentally and tact thoughts that lead to waste of time [7]. Also, this pattern can help management of organization to increase productivity and move towards sustainable development programs [8]. On the other hand, having a structured and specified safety management system pattern which complies with legal requirements can facilitate responsiveness of the organization in case of disasters and injuries. In general, safety management is an integral part of the activities of excellent training centres, in addition to taking advantage of it and avoiding many disasters, to prevent injury to financial

*Corresponding author: Yasamin Molavi Taleghani, Health Management and Economics Research Center, Isfahan University of Medical Sciences, Isfahan, Iran Tel: +989127233347; E-mail: yasamin_molavi1987@yahoo.com

Received October 08, 2018; Accepted October 15, 2018; Published November 08,2018

Citation: Taleghani YM, Jabbari A, Khorasani E, Asgari H, Mardani R (2018) Designing a Safety Management Model for Higher Education Centres. J Health Educ Res Dev 6: 279. doi: 10.4172/2380-5439.1000279

Copyright: @ 2018 Taleghani YM, et al. This is an open-access article distributed under the terms of the Creative Commons Attribution License, which permits unrestricted use, distribution, and reproduction in any medium, provided the original author and source are credited. 
Citation: Taleghani YM, Jabbari A, Khorasani E, Asgari H, Mardani R (2018) Designing a Safety Management Model for Higher Education Centres. J Health Educ Res Dev 6: 279. doi: 10.4172/2380-5439.1000279

resources and equipment of the organization, and consequently creating dissatisfaction [9]. In 2000, the UK Higher Education Budget Council required that all universities implement safety management as a governmental tool to increase productivity in decision making [10]. The safety management pattern in the higher education sector can include different sections, each of which has its own indexes. However, with the exception of big universities (with more than 15,000 full time enrolments), which are relatively advanced in their safety management programs, many centres, such as higher education centres in Iran, are in the early stages of maturity in safety management [4].

According to the presented articles, having an acceptable safety management pattern in higher education centres can prevent the complications caused by harmful issues to students and bring their potential talents closer to perfection, this study has been conducted with the aim of designing the safety management pattern for higher education centres in Iran in year of 2016.

\section{Methods}

The present study is a qualitative descriptive study that used reviewing different models and Delphi method to design a safety management pattern for higher education centres (Figure 1). This study was conducted in three main phases:

\section{First phase study phase}

In this phase, all of the world's educational and non-educational organizations that had been provided a model for safety and risk management as well as all reports, articles and related studies were evaluated.

Official websites, articles, reports, guidelines, and authoritative guidance of worldwide were used for collecting research data. Also, the English databases available at the Iranian National Digital Medicine Library (web of knowledge, PubMed, Springer, Google Scholar,

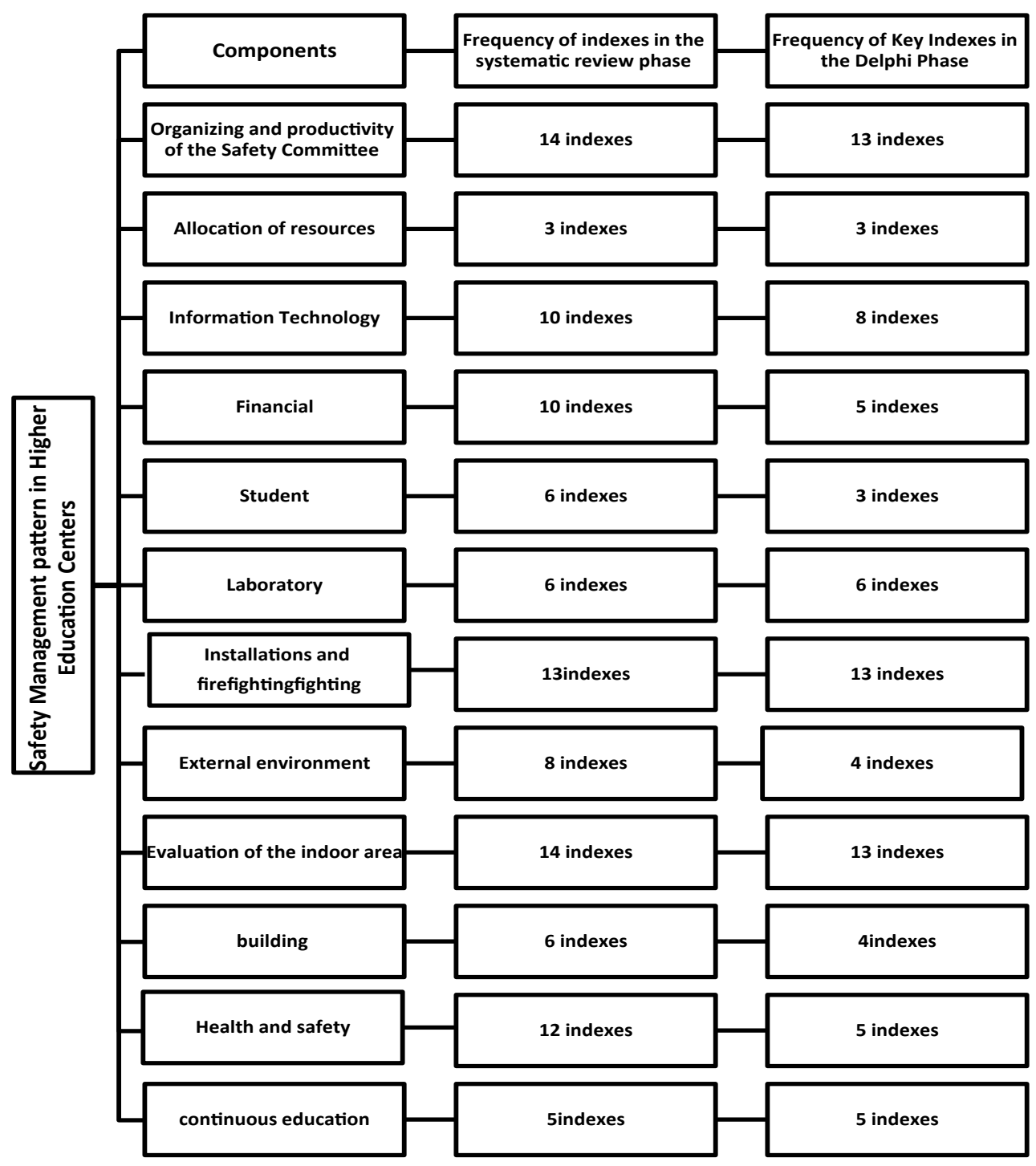

Figure 1: A Safety Management model for higher education centres 
Cochran, Elsevier) and the Persian SID database) and Magiran (and Google) were used in order to find articles and studies published electronically and without time limitations. search using Persian keywords: (safety, risk, safety and risk management, university and higher education) and English (risk or safety management, educational centres, Higher Education) was done separately or a combination with Boolean functions, as well as a list of reference published has been conducted to increase sensitivity and select more studies.

The search assessment was done by one of the researchers randomly to evaluate the non-deletion of the studies. Finally, related articles were selected and acted to remove non-related items. After determining the related studies, the assessment of the quality of the studies was evaluated through authors' agreement using the evaluating observation and avoiding errors by observing standards criteria. Extracting information by researchers based on title, type of text, authors, year, country, study purpose, title of safety or risk model, dimensions and indexes of safety and risk management, level and location of model implementation.

The criteria for the entry of studies and reports in this phase were related to safety and risk management and the presentation of dimensions or frameworks for safety and risk assessment. Also, the exit criteria of the studies included cases that have merely described the importance of safety and risk management and had been not provided any specific indexes or criteria.

\section{Second phase formation of the primary model}

In this phase, by determining the points of sharing and differentiation of the safety and risk management indexes extracted in the first phase, a preliminary draft was designed to determine the components of safety management in the educational centres of Iran by the authors. The prepared draft was also criticized and agreed by the research authors and 3 experts in the area of safety and risk management (One person at the Department of Health in Disasters and one assistant professor of disaster and one Ph.D. in Health Services Management).

\section{Third phase pattern validation}

The third phase was final pattern presentation of safety management and validation of this pattern by the Delphi method. All experts in the fields of educational management, risk and safety management were research population in this phase. Sampling was targeted in the field of experts and was used by those who had the expertise and experience required in this field. In this phase, the input criteria of the study include at least one of the following: 1. having related researches in safety and risk management (or) membership in specialized risk and safety committees (and) 2. Having a work experience in related organizations with the issue of safety and risk, or having work experience in higher education centres.

Participants in two rounds were rated each of the sub-dimension under study using a researcher-made questionnaire on the 5-point Likert scale (very low value $=1$, low value $=2$, Average value $=3$, high value $=4$, very high value $=5$ ). The number of participants included 20 people of experts. Three follow-ups were conducted to increase the responsiveness rate to a questionnaire by one of the researchers.

The scores obtained in the questionnaire were entered into the SPSS software version 21. In the first round, indexes were removed with a score of less than $50 \%$ and also indexes were accepted with a score of over $50 \%$. Also, indexes with a score of $50-75 \%$ were considered in the second round questionnaire after the proposed modifications proposed by the study group. After re-distributing and re-collecting questionnaires, the indexes that were scored over the $80 \%$ were suggested as final indexes for entering the final pattern.

The determination of face and content validity was done through reviewing the texts, the consensus of the authors' comments and the 3 experts mentioned in the second phase of the research, and the cases of difficulty level (difficulty in understanding the words and phrases), the proportion rate (proper proportion and relation of phrases with dimensions of the questionnaire (and ambiguity) (the probability of misunderstandings of phrases or insufficiency of words meanings) was investigated. heterogeneous items with research topic were identified, eliminated, or modified ultimately. Also, suitable new indexes and items were added due to the dimensions of safety.

\section{Results}

In the first phase, 4708 related articles or reports were obtained after searching for various sources. After evaluating repeated cases and after evaluating their title and summary, 178 items were selected for study of complete text, which out of 178 cases, 32 items were selected for the subject field to extract information.

In the second phase, the sharing points and differentiation of the studied studies in the first phase are determined and its results have been presented in Table 1.

Then, 111 key indexes in terms of 12 subject areas were determined using Table 1 and the consensus of the authors' views and 3 experts in the field of safety and risk management field.

In the Delphi stage, experts' opinions were gathered through a questionnaire to prioritize and determine the validity of 111 components identified. At this stage, 25 participants with a responsiveness rate of $75 \%, 5(33.3 \%)$ males and $10(66.7 \%)$ females. Also, $46.7 \%$ of the participants were aged between 30 and 40 years old, $6.7 \%$ had no teaching experience, and $40 \%$ had a degree in health care management. Also, the average responsiveness time for participants in the Delphi phase has been eight days (1 to 15 days). The results of this phase are presented in Table 2 by the twelve main dimensions of safety management indexes in higher education centres.

Based on Table 2, the average mean of participants' views on dimensions of the safety management framework in higher education centres in Iran has been equal to 4.32, with the highest mean for the dimension of the facilities and the fire department with an average of 4.59 and the lowest for the student dimension with an average of 4.10.

82 components as a key index of the safety management framework in higher education centres in Iran have been identified according to the Table 1, which among these the components of the need capability for funds to fields of the safety management, existence of escape stairs and emergency exit with clear guidance signs, Has paling and stairs, determining a plan and time schedule for evacuation of units due to internal and external events, the existence and control of extinguisher capsules, the existence of an alarm system and other warning systems, the need for existence of fire alarm system and sensitive identifiers are as a key component in Safety Management Framework at the Higher Education Centre in Iran.

\section{Discussion}

Education is a human right, universal and certain. In particular, education is important in enabling people to reach their full potential and achieve other their important rights. School safety and educational 
Citation: Taleghani YM, Jabbari A, Khorasani E, Asgari H, Mardani R (2018) Designing a Safety Management Model for Higher Education Centres. J Health Educ Res Dev 6: 279. doi: 10.4172/2380-5439.1000279

Page 4 of 11

\begin{tabular}{|c|c|c|}
\hline Row & Dimensions of safety & Indexes \\
\hline 1 & - & Number of students and reports related to occupational safety and health [11] \\
\hline 2 & Fires and Settlement & $\begin{array}{l}\text { The type and measurement of the materials used, the discharge time, the design building, the number of people in the laboratory } \\
\text { building, the ability to diagnose the risk or the probability of detection (the safety measurement), the frequency of the fire and the } \\
\text { accidental settlement [12] (Laboratory) } \\
\text { Fire alarm system, emergency and floors evacuation plan, warning signs in outlets, construction control due to combustion, } \\
\text { adequacy of storage of combustible materials and extinguisher caps and status of electricity services [13] }\end{array}$ \\
\hline 3 & $\begin{array}{l}\text { Building and } \\
\text { environment }\end{array}$ & $\begin{array}{l}\text { Building: } \\
\text { Dimensions and lists of rooms and all requirements for protection and maintenance such as (roof, plumbing, etc.), release of } \\
\text { noise, smoke and odor, the correctness of building structures, obstruction in pipes, sliding surfaces [13] } \\
\text { Environment: } \\
\text { - External environment: air temperature, surface and temperature moisture and ventilation, adequate light, water quality [13], } \\
\text { supplying required drinking water [14], indoor air quality [14] } \\
\text { - Acoustic environment: control of inoperative sounds [13], hearing protection [14] } \\
\text { Environmental and laboratories safety [15] } \\
\text { Radiation safety [14] } \\
\text { Adaptation to air pollution [14] } \\
\text { Determination of asbestos and lead issues [14] } \\
\text { Determination of hazardous materials and wastes [14] } \\
\text { public health: } \\
\text { public cleaning of buildings, control of rodents and insects [13] } \\
\text { Access and use by disabled [13] } \\
\text { Allocation of physical resources, conditions of facilities, capital projects [16] } \\
\text { Environmental [17] } \\
\text { Physical [18] } \\
\text { Facilities [18] } \\
\text { Ergonomics [14] } \\
\text { Criteria for Enclosure class: } \\
\text { Flooring status, electric wires and cables, adequate lighting for safe exit, easy access to stairs or ramps, window and opener } \\
\text { to open windows at high altitudes, furniture and accessories, use of portable equipment with high durability, use of a trolley for } \\
\text { moving heavy objects, fixed electric switches with socket, portable electrical equipment for example: audiovisual equipment, } \\
\text { controlling ventilation and heating and cooling equipment [19] } \\
\text { Structural Safety Assessment } \\
\text { Location and examination of site soil, cargo system, building height, plan and construction details, water examination [2] } \\
\text { Non-instrumental safety assessment } \\
\text { Preventing fire and safety from fire, safety against storms and steep winds, earthquake safety [2] }\end{array}$ \\
\hline 4 & Earthquake & $\begin{array}{l}\text { Fire alarm system, Emergency and floor drain plans, Alarm system, Emergency alarm signs on Emergency Exit, Locked cabinets } \\
\text { and drainage areas [13] }\end{array}$ \\
\hline 5 & Flood & supply and access to upper floors during floods, creating a warning system and supplying warning signs for highlands [13] \\
\hline 6 & Information Technology & $\begin{array}{l}\text { Communication systems, data protection, final user education, disasters responsiveness, network integrity, privacy, security, } \\
\text { supportive, system capacity (15)Data security, business, affiliation, data recovery, IT resource allocation [16] }\end{array}$ \\
\hline 7 & Affairs student & $\begin{array}{l}\text { Behavioral, Freedom of Expression, Crime on Campus, Experimental programs, financial assistance, Study Abroad [15] Student } \\
\text { Satisfaction, Registration Management, Determining Capacity, Health, Security, and Safety [16] }\end{array}$ \\
\hline 8 & Financial field & $\begin{array}{l}\text { Budget, Audit, Cash Management, Conflict of Interest, Contract and Purchase, Cost Management, bailout, Capital absorption, } \\
\text { Insurance, Long-Term Debt, Reserve Fund [15] } \\
\text { Financial market, internal control, financial commitments, operational costs, revenue sources, resource allocation [16] } \\
\text { Financial [17,18,20] } \\
\text { Organizational value, financial strategy and synergy and financial conflict, decision making to assess financial strategy parameters, } \\
\text { measure decisions and actions, commercialization of researches, budget contradiction, evaluating basic costs and additional } \\
\text { costs, costs for different purposes, expansion of activities related to contracts, Controlling and Managing Results, Financial } \\
\text { Indexes, Performance Measurement in Education, Cost Management, Data Dashboards creation, Standard Criteria [21] }\end{array}$ \\
\hline 9 & Research field & Research, copyright, clinical research, privacy, disclosure policy, spiritual property rights, technology transferring [15] \\
\hline 10 & Scientific field & Adjustment of academic programs, education, quality, allocation of scientific resources, integration of the scientific activities [16] \\
\hline 11 & Laboratory & $\begin{array}{l}\text { Chemical and physical properties of the materials, nature of the risk, physical and chemical properties of the warning system, the } \\
\text { risks associated with the materials, the level of exposure to the materials [22] laboratory safety [14] }\end{array}$ \\
\hline
\end{tabular}

Table 1: Points of sharing and differentiation of evaluated studies. 
Citation: Taleghani YM, Jabbari A, Khorasani E, Asgari H, Mardani R (2018) Designing a Safety Management Model for Higher Education Centres. J Health Educ Res Dev 6: 279. doi: 10.4172/2380-5439.1000279

Page 5 of 11

\begin{tabular}{|c|c|c|c|c|c|c|}
\hline \multicolumn{7}{|c|}{ Area of Organizing and Operating the Safety Committee or Disasters } \\
\hline Indexes & Mean & Very important & Important & Moderate & Non-significant & Unimportant \\
\hline $\begin{array}{l}\text { The need for the creating and holding a regular } \\
\text { safety committee in higher education centers }\end{array}$ & 4.46 & $9(60 \%)$ & $4(26.7 \%)$ & $2(13.3 \%)$ & 0 & 0 \\
\hline $\begin{array}{c}\text { The commitment and support of senior managers } \\
\text { to the principles of safety management (safety } \\
\text { culture) }\end{array}$ & 4.86 & $13(86.7 \%)$ & $2(13.3 \%)$ & 0 & 0 & 0 \\
\hline $\begin{array}{l}\text { The existence of a clear and structured style } \\
\text { sheet for the selection and appointment of } \\
\text { members of the Safety Committee }\end{array}$ & 4.26 & $6(40 \%)$ & $8(53.3 \%)$ & $1(6.7 \%)$ & 0 & 0 \\
\hline $\begin{array}{l}\text { Existence of job descriptions and clear scope } \\
\text { authority for committee / safety team }\end{array}$ & 4.53 & $9(60 \%)$ & $5(33.3 \%)$ & $1(6.7 \%)$ & 0 & 0 \\
\hline $\begin{array}{c}\text { Determining the safety interface at the level of } \\
\text { Subsidiary units }\end{array}$ & 4.46 & $9(60 \%)$ & $4(26.7 \%)$ & $2(13.3 \%)$ & 0 & 0 \\
\hline $\begin{array}{l}\text { Availability of regulations and guidelines issued } \\
\text { and determined by the Safety Committee at } \\
\text { Subsidiary Units }\end{array}$ & 4.13 & $5(33.3 \%)$ & $7(46.7 \%)$ & $3(20 \%)$ & 0 & 0 \\
\hline $\begin{array}{l}\text { Guarantee of execution of regulations and the } \\
\text { instructions issued and determined by the Safety } \\
\text { Committee in subsidiary units }\end{array}$ & 4.53 & $10(66.7 \%)$ & $4(26.7 \%)$ & $1(6.7 \%)$ & 0 & 0 \\
\hline $\begin{array}{l}\text { Developing policies and executive policy on } \\
\text { safety management field }\end{array}$ & 4.53 & $9(60 \%)$ & $5(33.3 \%)$ & $1(6.7 \%)$ & 0 & 0 \\
\hline $\begin{array}{l}\text { Executing guaranty of policy and executive } \\
\text { policy in the field of safety management by the } \\
\text { individual / guiding individuals }\end{array}$ & 4.33 & $8(53.3 \%)$ & $5(33.3 \%)$ & $1(6.7 \%)$ & $1(6.7 \%)$ & 0 \\
\hline $\begin{array}{l}\text { Identifying and prioritizing internal and external } \\
\text { risk factors in higher education centers }\end{array}$ & 4.73 & $11(73.3 \%)$ & $4(26.7 \%)$ & 0 & 0 & 0 \\
\hline $\begin{array}{l}\text { providing and availability of the program for the } \\
\text { overall management of disasters and internal } \\
\text { and external emergency cases }\end{array}$ & 4.46 & $9(60 \%)$ & $4(26.7 \%)$ & $2(13.3 \%)$ & 0 & 0 \\
\hline $\begin{array}{l}\text { Performing regular and moderated visits with a } \\
\text { safety management approach }\end{array}$ & 4.4 & $9(60 \%)$ & $3(20 \%)$ & $3(20 \%)$ & 0 & 0 \\
\hline $\begin{array}{l}\text { Establishing a mechanism to regularly obtaining } \\
\text { results of activities from subsidiary units to Board } \\
\text { of Directors of the University }\end{array}$ & 4.13 & $4(26.7 \%)$ & $9(60 \%)$ & $2(13.3 \%)$ & 0 & 0 \\
\hline $\begin{array}{l}\text { Provide periodic report from Colleges Safety } \\
\text { Status to the Board of Directors of the University }\end{array}$ & 3.93 & $4(26.7 \%)$ & $6(40 \%)$ & $5(33.3 \%)$ & 0 & 0 \\
\hline \multicolumn{7}{|c|}{ Resource Allocation Area } \\
\hline $\begin{array}{c}\text { Needs assessment for preventive facilities to } \\
\text { deal with disasters and Incidents by the Board of } \\
\text { Directors of the University }\end{array}$ & 4.4 & $7(46.7 \%)$ & $7(46.7 \%)$ & $1(6.7 \%)$ & 0 & 0 \\
\hline $\begin{array}{l}\text { Assignment of Preventive Resources in the } \\
\text { Event of Incidents and Disasters }\end{array}$ & 4.4 & $8(53.3 \%)$ & $6(40 \%)$ & $1(6.7 \%)$ & 0 & 0 \\
\hline $\begin{array}{l}\text { Identify and take protective measures from } \\
\text { resources within the university }\end{array}$ & 4.33 & $6(40 \%)$ & $8(53.3 \%)$ & $1(6.7 \%)$ & 0 & 0 \\
\hline \multicolumn{7}{|c|}{ Field of Continuing education } \\
\hline $\begin{array}{l}\text { Need assessment of educational programs in the } \\
\text { field of safety and work environment for internal } \\
\text { and external clients of the Institute }\end{array}$ & 4.64 & $9(64.3 \%)$ & $5(35.7 \%)$ & 0 & 0 & 0 \\
\hline $\begin{array}{c}\text { Setting up a desktop workout (based on } \\
\text { evidence-scenario) and performing hypothetical } \\
\text { maneuvers }\end{array}$ & 4.6 & $9(60 \%)$ & $6(40 \%)$ & 0 & 0 & 0 \\
\hline $\begin{array}{l}\text { Effective implementation of educational } \\
\text { programs and hypothetical maneuvers }\end{array}$ & 4.53 & $9(62.9 \%)$ & $3(23.1 \%)$ & 0 & $1(7.7 \%)$ & 0 \\
\hline $\begin{array}{l}\text { Evaluation of training programs and performed } \\
\text { maneuvers }\end{array}$ & 4.66 & $10(66.7 \%)$ & $5(33.3 \%)$ & 0 & 0 & 0 \\
\hline $\begin{array}{c}\text { Inclusion of safety training program in Job } \\
\text { promotion of staff }\end{array}$ & 4.46 & $8(53.3 \%)$ & $6(40 \%)$ & $1(6.7 \%)$ & 0 & 0 \\
\hline \multicolumn{7}{|c|}{ Student field } \\
\hline $\begin{array}{c}\text { Monitoring the Safety field of Managing } \\
\text { dormitories }\end{array}$ & 4.53 & $8(53.3 \%)$ & $7(46.7 \%)$ & 0 & 0 & 0 \\
\hline $\begin{array}{c}\text { Determine the health status, Security and safety } \\
\text { of students }\end{array}$ & 4.4 & $7(46.7 \%)$ & $7(46.7 \%)$ & $1(6.7 \%)$ & 0 & 0 \\
\hline $\begin{array}{l}\text { Identify the dimensions and types of crime on } \\
\text { campus }\end{array}$ & 4 & $6(40 \%)$ & $3(20 \%)$ & $6(40 \%)$ & 0 & 0 \\
\hline $\begin{array}{l}\text { Determine the method and measure the amount } \\
\text { of complaints and / or error report and potential } \\
\text { incidents }\end{array}$ & 4.26 & $4(26.7 \%)$ & $11(73.3 \%)$ & 0 & 0 & 0 \\
\hline
\end{tabular}


Citation: Taleghani YM, Jabbari A, Khorasani E, Asgari H, Mardani R (2018) Designing a Safety Management Model for Higher Education Centres. J Health Educ Res Dev 6: 279. doi: 10.4172/2380-5439.1000279

Page 6 of 11

\begin{tabular}{|c|c|c|c|c|c|c|}
\hline $\begin{array}{l}\text { Student training and counseling before, during } \\
\text { and after the incident to increase awareness and } \\
\text { resilience of students. }\end{array}$ & 3.86 & $5(33.3 \%)$ & $5(33.3 \%)$ & $4(26.7 \%)$ & 0 & $1(6.7 \%)$ \\
\hline $\begin{array}{l}\text { assessment of students about the fields of } \\
\text { safety, threatening risks, and coping strategies }\end{array}$ & 3.6 & $4(26.7 \%)$ & $4(26.7 \%)$ & $5(33.3 \%)$ & $1(6.7 \%)$ & $1(6.7 \%)$ \\
\hline \multicolumn{7}{|c|}{ Financial field } \\
\hline $\begin{array}{l}\text { The need for a dedicated budget for safety } \\
\text { management fields }\end{array}$ & 4.73 & $12(80 \%)$ & $2(13.3 \%)$ & $1(6.7 \%)$ & 0 & 0 \\
\hline Managing Organization Costs & 4 & $6(40 \%)$ & $5(33.3 \%)$ & $3(20 \%)$ & 0 & $1(6.7 \%)$ \\
\hline Create a reserve fund & 4.06 & $6(40 \%)$ & $4(26.7 \%)$ & $5(33.3 \%)$ & 0 & 0 \\
\hline Fundraising & 4.26 & $7(46.7 \%)$ & $6(40 \%)$ & $1(6.7 \%)$ & $1(6.7 \%)$ & 0 \\
\hline Identification of financial obligations & 3.9 & $4(26.7 \%)$ & $6(40 \%)$ & $5(33.3 \%)$ & 0 & 0 \\
\hline Ability to withdraw from the budget & 4.2 & $7(46.7 \%)$ & $6(40 \%)$ & $1(6.7 \%)$ & 0 & $1(6.7)$ \\
\hline Identify revenue sources & 4 & $5(33.3 \%)$ & $6(40 \%)$ & $3(20 \%)$ & $1(6.7 \%)$ & 0 \\
\hline $\begin{array}{l}\text { Establishment of the mechanism for the } \\
\text { insurance of occupational Incidents and civil } \\
\text { liability of staff for Incidents and disasters }\end{array}$ & 4.7 & $11(73.3 \%)$ & $4(26.7 \%)$ & 0 & 0 & 0 \\
\hline $\begin{array}{l}\text { Establishment of the mechanism for the } \\
\text { insurance of occupational Incidents and civil } \\
\text { liability of staff for Incidents and disasters }\end{array}$ & 4.6 & $11(73.3 \%)$ & $3(20 \%)$ & $1(6.7 \%)$ & 0 & 0 \\
\hline $\begin{array}{l}\text { Determination and decision making to assess the } \\
\text { parameters of financial strategies }\end{array}$ & 4 & $5(33.3 \%)$ & $6(40 \%)$ & $3(20 \%)$ & $1(6.7 \%)$ & 0 \\
\hline Control and audit of annual financial performance & 3.93 & $4(26.7 \%)$ & $7(46.7 \%)$ & $3(20 \%)$ & $1(6.7 \%)$ & 0 \\
\hline \multicolumn{7}{|c|}{ The field of information technology } \\
\hline Final user training & 4.46 & $9(60 \%)$ & $4(26.7 \%)$ & $2(13.3 \%)$ & 0 & 0 \\
\hline Determining data protection & 4.33 & $6(40 \%)$ & $8(53.3 \%)$ & $1(6.7 \%)$ & 0 & 0 \\
\hline Determining communication systems & 4.46 & $7(46.7 \%)$ & $8(53.3 \%)$ & 0 & 0 & 0 \\
\hline Network Integration & 4.20 & $7(46.7 \%)$ & $4(26.7 \%)$ & $4(26.7 \%)$ & 0 & 0 \\
\hline Creating privacy for users & 4.33 & $5(33.3 \%)$ & $10(67 \%)$ & 0 & 0 & 0 \\
\hline Provide network security & 4.53 & $9(60 \%)$ & $5(33.3 \%)$ & $1(6.7 \%)$ & 0 & 0 \\
\hline Determining the capacity of the IT system & 4.2 & $6(40 \%)$ & $6(40 \%)$ & $3(20 \%)$ & 0 & 0 \\
\hline Data and information continuity & 4 & $4(26.7 \%)$ & $7(46.7 \%)$ & $4(26.7 \%)$ & 0 & 0 \\
\hline $\begin{array}{l}\text { existence of supportive programs for data } \\
\text { recovery }\end{array}$ & 4.53 & $10(66.7 \%)$ & $3(20 \%)$ & $2(13.3 \%)$ & 0 & 0 \\
\hline $\begin{array}{c}\text { Identifying Preventive Plans for Information } \\
\text { Technology field in Response to Incidents and } \\
\text { disasters }\end{array}$ & 4.57 & $9(64.3 \%)$ & $4(26.7 \%)$ & $1(6.7 \%)$ & 0 & 0 \\
\hline \multicolumn{7}{|c|}{ Health and Safety field } \\
\hline $\begin{array}{l}\text { The existence of the responsible internal } \\
\text { organization in relation to occupational safety } \\
\text { and health issues }\end{array}$ & 4.2 & $5(33.3 \%)$ & $8(53.3 \%)$ & $2(13.3 \%)$ & 0 & 0 \\
\hline $\begin{array}{l}\text { Provision of health and safety programs for staff } \\
\text { and students by the Board of Directors }\end{array}$ & 4.28 & $6(42.9 \%)$ & $7(50 \%)$ & 0 & $1(7.1 \%)$ & 0 \\
\hline $\begin{array}{l}\text { The need for ongoing medical counseling to } \\
\text { support the safety program }\end{array}$ & 4 & $4(26.7 \%)$ & $7(46.7 \%)$ & $4(26.7 \%)$ & 0 & 0 \\
\hline $\begin{array}{l}\text { Need for determine the mechanisms to prevent } \\
\text { physical injuries of staff and students }\end{array}$ & 4.2 & $5(33.3 \%)$ & $9(60 \%)$ & 0 & $1(6.7 \%)$ & 0 \\
\hline $\begin{array}{l}\text { Determine and measure the harmful factors of } \\
\text { the work environment }\end{array}$ & 4.26 & $6(40 \%)$ & $8(53.3 \%)$ & 0 & $1(6.7 \%)$ & 0 \\
\hline The need for safety against radiation & 4.2 & $11(73.3 \%)$ & 0 & $2(13.3 \%)$ & 0 & $2(13.3 \%)$ \\
\hline The need to control inoperative sounds & 3.86 & $7(46.7 \%)$ & $3(20 \%)$ & $3(20 \%)$ & 0 & $2(13.3 \%)$ \\
\hline $\begin{array}{l}\text { The need for personal protective equipment and } \\
\text { facilities }\end{array}$ & 4.4 & $10(66.7 \%)$ & $3(20 \%)$ & $1(6.7 \%)$ & 0 & $1(6.7 \%)$ \\
\hline public cleaning of the building & 3.6 & $2(13.3 \%)$ & $7(46.7 \%)$ & $4(26.7 \%)$ & $2(13.3 \%)$ & 0 \\
\hline Determine hazardous materials and wastes & 4.2 & $9(60 \%)$ & $2(13.3 \%)$ & $3(20 \%)$ & 0 & $1(6.7 \%)$ \\
\hline Perform spraying to control rodents and insects & 3.93 & $5(33.3 \%)$ & $5(33.3 \%)$ & $4(26.7 \%)$ & $1(6.7 \%)$ & 0 \\
\hline $\begin{array}{l}\text { The need to establish a support phase and } \\
\text { following reports and inspections of staff } \\
\text { from potential risks and possible incidents at } \\
\text { workplace }\end{array}$ & 4.26 & $7(46.7 \%)$ & $5(33.3 \%)$ & $3(20 \%)$ & 0 & 0 \\
\hline \multicolumn{7}{|c|}{ Building area } \\
\hline $\begin{array}{c}\text { Presence of Building Use Identity for Higher } \\
\text { Education Centers }\end{array}$ & 4.26 & $7(46.7 \%)$ & $5(33.3 \%)$ & $3(20 \%)$ & 0 & 0 \\
\hline $\begin{array}{l}\text { The need to determine the list and dimensions } \\
\text { of the rooms and all maintenance and protection } \\
\text { requirements such as (roof, plumbing, etc.) }\end{array}$ & 4.26 & $7(46.7 \%)$ & $5(33.3 \%)$ & $3(20 \%)$ & 0 & 0 \\
\hline
\end{tabular}


Citation: Taleghani YM, Jabbari A, Khorasani E, Asgari H, Mardani R (2018) Designing a Safety Management Model for Higher Education Centres. J Health Educ Res Dev 6: 279. doi: 10.4172/2380-5439.1000279

Page 7 of 11

\begin{tabular}{|c|c|c|c|c|c|c|}
\hline $\begin{array}{l}\text { The need to determine the correctness of } \\
\text { building structures and their correct use }\end{array}$ & 4.33 & $7(46.7 \%)$ & $6(40 \%)$ & $2(13.3 \%)$ & 0 & 0 \\
\hline $\begin{array}{c}\text { The need to determine the accuracy of slider } \\
\text { surfaces (stairs, ramps, etc.) and their correct } \\
\text { use }\end{array}$ & 4.2 & $6(40 \%)$ & $6(40 \%)$ & $3(20 \%)$ & 0 & 0 \\
\hline evaluating design and construction details & 4.13 & $6(40 \%)$ & $5(33.3 \%)$ & $4(26.7 \%)$ & 0 & 0 \\
\hline evaluating the height of the building & 3.93 & $6(40 \%)$ & $4(26.7 \%)$ & $3(20 \%)$ & $2(13.3 \%)$ & 0 \\
\hline \multicolumn{7}{|c|}{ The field of assessment of the indoor area } \\
\hline Determine the condition of the floor covering & 4.13 & $5(33.3 \%)$ & $7(46.7 \%)$ & $3(20 \%)$ & 0 & 0 \\
\hline $\begin{array}{l}\text { The need to determine the function of the } \\
\text { blockage in the tubes }\end{array}$ & 4.42 & $7(50 \%)$ & $6(42.9)$ & $1(7.1 \%)$ & 0 & 0 \\
\hline $\begin{array}{l}\text { Existence of window and door handle to open } \\
\text { the windows at high altitude }\end{array}$ & 4.26 & $6(40 \%)$ & $7(46.7 \%)$ & $2(13.3 \%)$ & 0 & 0 \\
\hline $\begin{array}{c}\text { Control of ventilation and heating and cooling } \\
\text { equipment }\end{array}$ & 4.4 & $7(46.7 \%)$ & $7(46.7 \%)$ & $1(6.7 \%)$ & 0 & 0 \\
\hline Easy access to stairs or ramps & 4.53 & $9(60 \%)$ & $5(33.3 \%)$ & $1(6.7 \%)$ & 0 & 0 \\
\hline $\begin{array}{c}\text { The presence of escape stairs and emergency } \\
\text { exits with clear signs of guidance with paling and } \\
\text { stairs }\end{array}$ & 4.73 & $12(80 \%)$ & $2(13.3 \%)$ & $1(6.7 \%)$ & 0 & 0 \\
\hline $\begin{array}{c}\text { Determining adequate lighting for safe } \\
\text { evacuation }\end{array}$ & 4.4 & $8(53.3 \%)$ & $5(33.3 \%)$ & $2(13.3 \%)$ & 0 & 0 \\
\hline Accessibility of audiovisual equipment & 4.06 & $6(40 \%)$ & $4(26.7 \%)$ & $5(33.3 \%)$ & 0 & 0 \\
\hline $\begin{array}{l}\text { Accessibility and use of facilities by disabled } \\
\text { people }\end{array}$ & 4.46 & $7(46.7 \%)$ & $8(53.3 \%)$ & 0 & 0 & 0 \\
\hline $\begin{array}{l}\text { Accessibility and use of the carriage for the } \\
\text { transfer of heavy objects }\end{array}$ & 4.2 & $6(40 \%)$ & $8(53.3 \%)$ & $1(6.7 \%)$ & $1(6.7 \%)$ & 0 \\
\hline The presence of lockers and cabinets & 4.06 & $4(26.7 \%)$ & $8(53.3 \%)$ & $3(0 \%)$ & 0 & 0 \\
\hline fixed electric switches with connection sockets & 4.33 & $7(46.7 \%)$ & $6(40 \%)$ & $2(13.3 \%)$ & 0 & 0 \\
\hline $\begin{array}{l}\text { Determine the status of electrical wires and } \\
\text { cables }\end{array}$ & 4.26 & $6(40 \%)$ & $7(46.7 \%)$ & $2(13.3 \%)$ & 0 & 0 \\
\hline Supply and access to upper floors during floods & 4.4 & $7(46.7 \%)$ & $7(46.7 \%)$ & $1(6.7 \%)$ & 0 & $\mathbf{0}$ \\
\hline \multicolumn{7}{|c|}{ The area of the external environment } \\
\hline $\begin{array}{c}\text { Determine the temperature of air, moisture and } \\
\text { ventilation }\end{array}$ & 3.73 & $2(13.3 \%)$ & $7(46.7 \%)$ & $6(40 \%)$ & 0 & 0 \\
\hline $\begin{array}{l}\text { Suitable natural daylight and artificial light with } \\
\text { an international standard of intensity }\end{array}$ & 3.66 & $2(13.3 \%)$ & $6(40 \%)$ & $7(46.7 \%)$ & 0 & 0 \\
\hline Determine indoor air quality of building & 4.06 & $5(33.3 \%)$ & $6(40 \%)$ & $4(26.7 \%)$ & 0 & 0 \\
\hline Determine the quality of drinking water & 4.46 & $9(60 \%)$ & $4(26.7 \%)$ & $2(13.3 \%)$ & 0 & 0 \\
\hline Evaluating water reserves & 4.33 & $7(46.7 \%)$ & $6(40 \%)$ & $2(13.3 \%)$ & 0 & 0 \\
\hline evaluating the site soil & 4.14 & $5(35.7 \%)$ & $6(42.9 \%)$ & $3(21.4 \%)$ & 0 & 0 \\
\hline $\begin{array}{l}\text { Existence of earthquake and flood safety } \\
\text { programs }\end{array}$ & 4.64 & $9(64.3 \%)$ & $5(35.7 \%)$ & 0 & 0 & 0 \\
\hline $\begin{array}{l}\text { Existence of safety program against storms, } \\
\text { steep winds and other hazards }\end{array}$ & 4.35 & $7(50 \%)$ & $5(35.7 \%)$ & $2(14.3 \%)$ & 0 & 0 \\
\hline \multicolumn{7}{|c|}{ Utilities and fire department } \\
\hline $\begin{array}{c}\text { Determine the plan and time schedule for } \\
\text { discharging units due to internal and external } \\
\text { events }\end{array}$ & 4.73 & $11(73.3 \%)$ & $4(26.7 \%)$ & 0 & 0 & 0 \\
\hline $\begin{array}{c}\text { Identification of hazardous and fire hazardous } \\
\text { places and identifying these places in higher } \\
\text { education centers }\end{array}$ & 4.6 & $9(60 \%)$ & $6(40 \%)$ & 0 & 0 & 0 \\
\hline $\begin{array}{c}\text { Existence of fire prevention program and fire } \\
\text { safety }\end{array}$ & 4.66 & $10(66.7 \%)$ & $5(33.3 \%)$ & 0 & 0 & 0 \\
\hline $\begin{array}{c}\text { Develop programs to deal with the fire, according } \\
\text { to fire codes and rules }\end{array}$ & 4.53 & $9(60 \%)$ & $5(33.3 \%)$ & $1(6.7 \%)$ & 0 & 0 \\
\hline $\begin{array}{l}\text { The need for a fire alarm system and sensitive } \\
\text { identifiers }\end{array}$ & 4.73 & $12(80 \%)$ & $2(13.3 \%)$ & $1(6.7 \%)$ & 0 & 0 \\
\hline $\begin{array}{c}\text { The existence of an alarm system and other } \\
\text { warning systems }\end{array}$ & 4.73 & $11(73.3 \%)$ & $4(26.7 \%)$ & 0 & 0 & 0 \\
\hline Existence and controlling extinguishing Capsules & 4.73 & $11(73.3 \%)$ & $4(26.7 \%)$ & 0 & 0 & 0 \\
\hline Settlement detection system & 4.66 & $10(66.7 \%)$ & $5(33.3 \%)$ & 0 & 0 & 0 \\
\hline The ability to identify or probability of fire & 4.6 & $9(60 \%)$ & $6(40 \%)$ & 0 & 0 & 0 \\
\hline $\begin{array}{c}\text { Creation of a cooling, heating and ventilation } \\
\text { maintenance program for higher education } \\
\text { centers }\end{array}$ & 4.33 & $7(46.7 \%)$ & $6(40 \%)$ & $2(13.3 \%)$ & 0 & 0 \\
\hline
\end{tabular}




\begin{tabular}{|c|c|c|c|c|c|c|}
\hline $\begin{array}{l}\text { developing control program of generator function } \\
\text { and emergency power supply systems }\end{array}$ & 4.4 & $7(46.7 \%)$ & $7(46.7 \%)$ & $1(6.7 \%)$ & 0 & 0 \\
\hline $\begin{array}{c}\text { Existence of necessary measures to prevent } \\
\text { the spread of smoke and air pollutants through } \\
\text { the powerhouse to other university / college } \\
\text { buildings. }\end{array}$ & 4.4 & $8(53.3 \%)$ & $5(33.3 \%)$ & $2(13.3 \%)$ & 0 & 0 \\
\hline Control the status of electricity services & 4.57 & $8(57.1 \%)$ & $6(42.9 \%)$ & 0 & 0 & 0 \\
\hline \multicolumn{7}{|c|}{ Laboratory area } \\
\hline $\begin{array}{c}\text { Determine the hazards associated with the } \\
\text { material }\end{array}$ & 4.6 & $10(66.7 \%)$ & $4(26.7 \%)$ & $1(6.7 \%)$ & 0 & 0 \\
\hline Determine the nature of the risk & 4.46 & $8(53.3 \%)$ & $6(40 \%)$ & $1(6.7 \%)$ & 0 & 0 \\
\hline $\begin{array}{l}\text { Determination of the level of exposure to } \\
\text { materials }\end{array}$ & 4.46 & $8(53.3 \%)$ & $6(40 \%)$ & $1(6.7 \%)$ & 0 & 0 \\
\hline $\begin{array}{l}\text { Measure chemical and physical properties of } \\
\text { materials }\end{array}$ & 4.26 & $7(46.7 \%)$ & $5(33.3 \%)$ & $3(20 \%)$ & 0 & 0 \\
\hline $\begin{array}{c}\text { Matching alarm systems according to the } \\
\text { physical and chemical properties of laboratory } \\
\text { materials }\end{array}$ & 4.46 & $8(53.3 \%)$ & $6(40 \%)$ & $1(6.7 \%)$ & 0 & 0 \\
\hline $\begin{array}{l}\text { Separation and storage of hazardous and } \\
\text { flammable materials in a safe place }\end{array}$ & 4.66 & $10(66.7 \%)$ & $5(33.3 \%)$ & 0 & 0 & 0 \\
\hline
\end{tabular}

Table 2: Frequency distribution of participants on indexes of safety management pattern in higher education centers.

continuing require a continuous and dynamic process initiated by management and staff involved students, parents and the local community [23]. Hence, considering the importance of reducing the vulnerability of universities, due to the availability of human, scientific, documentary and equipment assets, it is imperative to develop a safety management program. Therefore, this study was conducted with the aim of studying the design of safety management pattern of high education centres in Iran in year of 2015.

In the review phase of text, after reviewing the studies and evaluating safety management models in educational and non-educational organizations in the world, 111 indexes were obtained based on 12 classes. In general, extensive studies have been conducted in other countries on the assessment of safety management in higher education centres, but unfortunately, there are no comprehensive indexes that have considered all aspects of the assessment of these centres in Iran.

The history of developing disasters and incidents risk management plans in the college campus area is very young and it dates back to the late twentieth century [24]. Safety unit of the US Department of Education provides executive framework for realization of the program as following steps: organizing, identifying hazards and vulnerabilities, providing or developing a crisis management plan and applying and implementing it at universities $[25,26]$. Beatriz Ferna et al. in their study considered the determining the work policies Incentives, training, communication, planning (reactive and preventive), control (internal and benchmarking) as dimensions of the safety management system [27]. In addition, Vaughen et al. have mentioned the organizational design, organizational changes, monitoring and supporting, training and staff competence, communications, resource and facilities provision, operational procedures, work permits, and resource allocation in emergency condition as components of improving the performance of the safety process [28]. In 2008, Liou et al. described the dimensions of policy and strategy, feedback and monitoring, event analysis, determining and allocating resources, and training and empowering the human resources as essential components of safety management [29]. In addition, Murat Gunduz et al. mentioned the essential components of designing the safety management of enterprises as determining mission and outlook related to safety, determining and evaluating goals, prioritizing passages, innovations, determining the passages of performance evaluation and performance measurement [30]. In the third phase of the study, the average mean of participants' views on the dimensions of the safety management framework in higher education centres in Iran has been equal to 4.32, with the highest average for the dimension of the facilities and the firefighting department with a mean of 4.59 , and the lowest has been related to the student dimension with an average of 4.1. Finally, with $82 \%$ reliability, 82 components were identified as key indexes of the safety management framework in higher education centres of Iran.

In the field of organizing and productivity of the safety or Incident committee, 13 components were identified as key components of this field. One of the best indexes that show establishing a safe and good condition in the organization is the existence of a positive attitude toward safety throughout the organization [31]. Management, in collaboration with the Safety and Incident Committee, should develop safety plans to address potential deficiencies, preventing hazard and appropriate performance when there is a risk in the organization [32]. Zaboli et al. also mentioned in their study the organizing and productivity of the safety or Incident committee as one of the key components of safety management at Baqi Allah Hospital, which is in line with the present study [33]. In the area of resource allocation, three components were identified as key components of this field. The disaster and incident management system needs resources and facilities to prevent and manage incidents and disasters and the crises caused by them [34]. In order to improve the performance of higher education, funding allocation has also been welcomed as an effective and efficient solution [35]. In general, planning, organizing and directing resources should be done in the event of incidents and disasters [36].

In the field of continuing education, 5 indexes were determined as key indexes of this field. People's education and community readiness are very effective in dealing with disasters and incidents [37]. Omidvari in his study has also pointed to the empowerment and reduction of vulnerability of higher education centres through education and the creation of appropriate structures for a higher education centre that is consistent with the present study [12]. Also, Mohammad Amiri et al. have emphasized in their study that the needs assessment and holding training courses in field of disasters for managers and personnel plays an important role in increasing the level of organization's readiness. In general, the high awareness of the medical staff can be effective in improving the safety of the organization [38].

In the student field, indexes of monitoring the dormitory's safety 
area, determining the status of health, safety and security of students, and determining the method and scale assessment of complaint and / or error reporting and potential incidents were identified as the main indexes of this area. Student dormitory for many young people is an inadequate substitute for the family's safe environment. Having support and living with the family is one of the most important psychological and emotional needs of all age groups. So the safety of the dormitory management should be on the agenda.

In the financial field, 5 components have been identified as key components of this area. Today, countries are trying to recreate their higher education financing system in a way to realize development objectives even better and more [39]. Also, occupational incident insurance is not just a source of compensation for financial losses from incidents, but it can also be used with the proper policy of insurance to prevent abnormal incidents. This requires changing the look of insurance and, if necessary, preparing and developing new rules and regulations [40].

In the field of information technology, 8 indexes were identified as key indexes of this field. Communicating and informing among organs and people are the first step in disaster planning and management [41]. Therefore, the use of an effective system of preventing incidents requires a conscious exposure to the environment and accurate, getting correct, accurate and up-to-date information. Also, studies have been conducted on the confidentiality and security of data and information related to patients in the hospital information system, among them the Fernando and Dawson's study can be mentioned [42].

5 indexes were identified as key indexes of health and safety field. What is effective in continuous improvement in an organization and its productivity and profitability is human health and environmental protection. Therefore, any status that can lead to the preservation and protection of these causes actually increases productivity in the organization [43]. In order to improve HSE status, it is important to pay attention to some of the features, such as competence history, education, competitive spirit, and environmental knowledge [44]. Axorn also explains that factors such as management support, effective program planning, program evaluation, proper monitoring, control system and safety precautions and teamwork are effective in implementing safety plans [45]. In the field of building, 4 components were identified as key components of this field. Modern construction laws do not provide sufficient safety for patients in hospitals in different circumstances [46] User identity and construction requirements minimum requirements for building design and construction and balance provides between the best in safety and economic facilities.

In the field of assessing indoor area of building, thirteen indexes were identified as key indexes of this field. The safety of the building's indoor area is to provide a series of facilities (in compliance with legal criteria) in the building [13]. Which, in addition to securing and maintaining health conditions, also creates a willingness to work in the workers, which safety point on ladders, stairs, floors, ceilings, elevators and so on can be mentioned.

Four indexes were identified as key indexes of the external environment. Nowadays, the complications and injuries to life and property caused by natural disasters and the external environment has a tremendous impact on the lives of humans, to the extent that destructive effects disturb the ability of a society to meet basic needs $[47,48]$. Therefore, the US government describes the establishment of a plan for health care centres as a starting point for the safety of academic environments against disasters. In addition to emphasizing the need for formation of planning groups and crisis advisory committees at universities and flexibility in the programs, the program emphasizes the need for regular review and monitoring [49].

In the area of installations and firefighters, 13 indexes were identified as key indexes of this field. According to the results of a study, all fire damage occurs while using safety principles, $75 \%$ of the fires are before prediction and prevention [50]. Zamanian et al. in their study, offered solutions such as the fitting of fire hydrants with suitable water pressure, firefighting boxes, existence of firefighting capsules that are controlled and charged periodically and embedded in alarm system and fire extinguishing and emergency aid boxes to reduce the risks of fire [51-53].

One of the limitations of the research was the limitations of articles in the field of safety management in the phase of study search. Therefore, researchers tried to increase the thematic scope of the research and used the keywords of risk management and safety management in the study phase to increase the articles and subsequently to increase the search precision. However, in the synthesis and assessment section of the quality of articles, only articles were entered in the research findings which have had a perfect match with the practical definition of safety management mentioned in the definition of vocabulary.

Also, in this study, the design of safety management pattern in higher education centres has been extracted through a review of the studies, some of the components and dimensions of safety management in higher education centres have not been studied in Iran and in the world, and this has been led to lake of identification of these components in the final pattern.

\section{Conclusion}

The safety management system is an official framework for safety in performing daily activities that includes safety policy, safety and executive goals, risk assessment, responsibilities and authorities, regulations and procedures, and monitoring and assessment processes. The safety management framework in various studies, although are apparently different, but in fact they all seek to determine key aspects and indexes for an appropriate assessment of safety management. Therefore, it is imperative that university administrators should set up the system in their higher education centres with command lines and delegated authorities and organizational and legal tools while aware of the dimensions and components of safety management. As well as a safety policy in each organization should be verified and supported by high-level management and the safety goals of the institute should be clear.

Finally, it can be said that safety is not isolated from other matters and is mixed with all human and machine activities but it's effective and realistic, when to be associated with detailed inspection plans and the existence of safety plans, training, exercises, and exercise to incidents and disasters. In this research, some key dimensions in the field of safety management have not been extracted due to the limitation in data collection method. Therefore, it is suggested that a more comprehensive model to be designed for safety management in higher education centres with comprehensive evaluation.

\section{Conflict of Interest Statement}

The authors certify that they have NO affiliations with or involvement in any organization or entity with any financial interest, or non-financial interest in the subject matter or materials discussed in this manuscript. 


\section{Funding}

No funding.

\section{References}

1. Kageyama A (2014) The Implementation Process of Enterprise Risk Management in Higher Education Institutions. International Review of Business 14: $61-80$.

2. Ellena G (2010) Disaster and Emergency Preparedness: Guidance for Schools. Washington DC, USA: International Finance Corporation, World Bank Group.

3. Daigneau W, Valenti M, Ricciarini S, Bender S, Alleyne N, et al. (2005) Planning, Designing and Managing Higher Education Institutions. OECD Publishing.

4. Aiello M (2012) Risk in Canada's Higher Education Landscape a Survey of Canadian Universities and College. Marsh Risk Consulting.

5. University Of London Guide to Risk Management. University Of London, 2009.

6. Zaboli R, Tofighi SH, Delavari A;'Mirhashemi S» (2007) Survey of Safety Management On Bagiyatallah (a.s) Hospital, 2006-07|. Journal of Military Medicine 9: 103-111.

7. MHT (2006) Health, Safety and Environment Management; A creative approach to sustainable development. Iran Occupational Health 3: 1-5.

8. Risk Management in Higher Education. Higher education funding council for the England, 2005.

9. Farshad A, Khosravi Y, Alizade S (2006) The role of HSE management system to improve the performance of health, safety and Environment of Organizations and Sustainable Development (Case Study). Iran Occupational Health 3: 6-11.

10. Huber M (2011) Risk identification at higher education institutions in England London School of Economics and Political Science.

11. England HEFF (2005) Risk management in higher education A guide to good practice, prepared for HEFCE by PricewaterhouseCoopers. Higher Education Funding Council for England, p: 1-41.

12. Omidvari M, Mansouri N (2015) Fire and spillage risk assessment pattern in scientific laboratories. International Journal of Occupational Hygiene 6: 68-74.

13. Lapus JA, Bacani RC, Mateo JLR, Hernandez OR (2010) DepEd Educational Facilities Manual (Revised Edition of the 2007 Handbook on Educational Facilities-Integrating Disaster Risk Reduction in School Construction).

14. Safety DoEH (2010) California State University, Fresno Risk Management Environmental Health \& Safety Policy. California: Environmental Health \& Safety, pp: 1-2.

15. Colleges (AGB) AoGBoUa (2009) The State of Enterprise Risk Management at Colleges and Universities Today. Washington: United Educators, pp: 1-32.

16. Administration moWLss (2011) Wilfrid Laurier University Enterprise Risk Management Draft Final Report. Australia: Deloitte \& Touche LLP and affiliated entities.

17. Savage A (2007) Applying Risk Management in a University Environment to Manage the Risk of Fraud and Corruption. APSAC; Australian Public Sector Anti-Corruption Conference, pp: 1-12.

18. Olvera C (2010) Risk management for Student organization Advisors. Wisconsin: NCSL (National Center for Student leadership).

19. The Department for Education WAGaSG (2008) Health and safety checklist for classrooms. UK: Health and Safety Executive, pp: 1-3.

20. Ruzic-Dimitrijevic L, Dakic J (2014) The risk management in higher education institutions. Online Journal of Applied Knowledge Management 2: 137-152.

21. Sutela M, Aartsen PJ (2014) Financing Instruments for Higher Education \& Research Institutions: Financial KPIs, Risk Management, Commercialisation. European Seminar Berlin: The European Academy for Taxes, Economics \& Law reserves, pp: 1-11.

22. MEMBER OSaH (2006) Respiratory Protection Program: University of Notre Dame. Indiana: University of Notre Dame.

23. Disaster and Emergency Preparedness: Guidance for Schools: International Finance Corporation; 2010.
24. Disaster Reduction of University Campuses in the America (DRUCA) (2005) Orientation Document of Guideline Material. Washington D.C: Working Document.

25. Arnold C (2006) Designing for Earthquakes: A Manual for Architects. Mimari Tasarımda Deprem, Fema, p: 454.

26. FEMA (2003) Building a Disaster-Resistant University. US Department of Homeland Security. 2003.

27. Fernández-Muñiz B, Montes-Peon JM, Vazquez-Ordas CJ (2007) Safety management system: Development and validation of a multidimensional scale. Journal of Loss Prevention in the Process Industries 20: 52-68.

28. Vaughen BK, Downes A, Fox J, Belonger D (2015) Guidelines for integrating management systems and metrics to improve process safety performance. Process Safety Progress 34: 259-266.

29. Liou JJ, Yen L, Tzeng GH (2008) Building an effective safety management system for airlines. Journal of Air Transport Management 14: 20-26.

30. Gunduz M, Simsek B (2007) A strategic safety management framework through balanced scorecard and quality function deployment. Canadian Journal of Civil Engineering 34: 622-630.

31. Patankar MS, Sabin E, Salas E, Maurino D (2010) The safety culture perspective. Human Factors in Aviation, pp: 95-122.

32. Abdi Z, Maleki M, Khosravi A (2009) Staff perceptions of patient safety culture in selected hospitals of Tehran medical sciences university. Payesh Journal 10: $411-420$.

33. Zaboli R (2007) Survey of Safety Management on Bagiyatallah (as) Hospital, 2006-2007|. Journal Mil Med 9: 103-111.

34. Odden A, Clune WH (1998) School finance systems: Aging structures in need of renovation. Educational Evaluation and Policy Analysis 20: 157-177.

35. Vegas E, Hoxby C, Mcewan P, Vargas J, Mizala R (2002) School Choice, Student Performance, and Teacher and School Characteristics: The Chilean Case. World Bank Policy Research Working Paper No. 1999.

36. Djalali A, Castren M, Khankeh H, Gryth D, Radestad M, et al. (2013) Hospita disaster preparedness as measured by functional capacity: a comparison between Iran and Sweden. Prehospital and Disaster Medicine 28: 454-461.

37. Manouchehr O (2011) Investigation of the crisis management system and method of risk assessment for educational center (Case study: science and research Branch, IAU). Tehran: Islamic Azad University Science and Research Branch.

38. Bradley E, Hynam B, Nolan P (2007) Nurse prescribing: reflections on safety in practice. Social Science \& Medicine 65: 599-609.

39. Johnstone DB, Marcucci P (2010) Financing higher education in internationa perspective: Who pays? Who should pay?. Baltimore: The Johns Hopkins University Press 2010

40. Bochmann F, Arning M, Sun Y, Nold A (2015) Reduction of Occupational Accidents: Evidence based Prevention and the Prevention Index (PI TOP). International Journal of Epidemiology 44: i171-i172.

41. Gonzalez JJ, Turoff M, Dugdale J (2015) Introduction to the Communication and Information Systems Technology for Crisis and Disaster Management.

42. Fernando JI, Dawson LL (2009) The health information system security threa lifecycle: An informatics theory. International Journal of Medical Informatics 78 815-826.

43. Binagwaho A, Kyamanywa $P$, Farmer PE, Nuthulaganti T, Umubyeyi B, et al. (2013) The human resources for health program in Rwanda-a new partnership. New England Journal of Medicine 369: 2054-2059.

44. Hou X, Zhang Q, Qu X, Ma Z (2009) The effective contractor management in international oil cooperation. Asia Pacific Health, Safety, Security and Environment Conference. 2009: Society of Petroleum Engineers.

45. Aksorn T, Hadikusumo B (2008) Critical success factors influencing safety program performance in Thai construction projects. Safety Science 46: 709727.

46. Nystedt F (1999) Tolerable Fire Risk Criteria for Hospitals. Lund University, Sweden, p: 3101.

47. Cote AE, Grant CC, Hall JR, Powell PA, Solomon RE (2008) Fire protection handbook: National Fire Protection Association. 
Citation: Taleghani YM, Jabbari A, Khorasani E, Asgari H, Mardani R (2018) Designing a Safety Management Model for Higher Education Centres. J Health Educ Res Dev 6: 279. doi: 10.4172/2380-5439.1000279

48. Nivolianitou Z, Synodinou B (2011) Towards emergency management of natural disasters and critical accidents: The Greek experience. Journal of Environmental Management 92: 2657-2665

49. FEMA (2003) Building a Disaster-Resistant University In: Security UDoH. Washington DC, United States: FEMA, pp: 1-55

50. Beranek J (2005) Hot new options for hospital fire safety. Occupational Health \& Safety (Waco, Tex) 32: 4-6.
51. Zamanian Z, Evazian M, Hazeghi I, Daneshmandi H (2015) Fire safety status in the hospitals of Shiraz University of Medical Sciences, Shiraz, Iran. International Journal of Occupational Hygiene 5: 96-100.

52. WHO (2012) Laboratory Quality Management System Training Toolkit.

53. WHO (2008) Joint WHO-CDC Conference on Health Laboratory Quality Systems. France: World Health Organization, p: 21. 